\title{
Characteristics of the CFU-s population in mice carrying the Si ${ }^{\mathrm{j}}$ allele
}

\author{
R. E. Ploemacher and N. H. C. Brons \\ Department of Cell Biology and Genetics, Erasmus University, Rotterdam, The Netherlands
}

(Received 15 August 1982; revision accepted 28 June 1983)

\begin{abstract}
A tentative characterization of haemopoietic stem cells with respect to their organ distribution, seeding fraction and colony formation in the spleen, radiosensitivity and humoral regulation was attempted in mice heterozygous for the mutant allele $\mathrm{Sl}^{\mathrm{j}}$ and in their normal littermates. $\mathrm{Sl}^{\mathrm{j}} /+$ mice were characterized by a deficient CFU-s content of the blood and spleen and had slightly lower femoral CFU-s numbers. This CFU-s distribution could not be explained by differences in seeding efficiency ' $\mathrm{f}$ ' between CFU-s of $\mathrm{Sl}^{\mathrm{j}} /+$ and $+/+$ origin in lethally irradiated recipients used in the CFU-s assay. The seeding fraction of CFU-s of $+1+$ origin did not differ in $+/+$ and $\mathrm{Sl}^{j} /+$ recipients. However, in irradiated $\mathrm{Sl}^{\mathrm{j}} /+$ recipient mice a $30 \%$ decrease was observed in the number of the colonies derived from splenic and femoral CFU-s of both $+/+$ and $\mathrm{Sl}^{\mathrm{j}} /+$ origin. The serum level of SHSF (splenic haemopoiesis stimulating factor) was decreased in $\mathrm{Sl}^{\mathrm{j}} /+$ mice, but significantly increased in $\mathrm{Sl} / \mathrm{Sl}^{d}$ mice, as compared to their respective normal $+/+$ littermates. Endogenous colony formation in $\mathrm{Sl}^{\mathrm{j}} /+$ spleens was deficient in comparison to that observed in $+/+$ spleens, and distinct sex differences were observed. However, mutant and normal CFU-s from spleen and bone marrow had a similar survival following in-vitro $\gamma$ irradiation.

Femurs and spleens of both $\mathrm{Sl}^{3} /+$ and $+/+$ origin were implanted into both $\mathrm{Sl}^{\mathrm{j}} /+$ and $+/+$ hosts. Six weeks later the $\mathrm{SI}^{\mathrm{j}} /+$ grafts contained less CFU-s than the $+/+$ grafts.

These data show that the splenic stroma of $\mathrm{Sl}^{\mathrm{j}} /+$ mice is not defective in its capacity to lodge injected CFU-s but is deficient in its ability to maintain CFU-s under 'steady-state' conditions and stimulate their colony formation in a 'perturbed state'. Some of the characteristics of $\mathrm{Sl}^{\mathrm{j}} /+$ mice segregate them from Sl/Sl mice, i.e. a deficient splenic CFU-s content, normal seeding fractions ' $\mathrm{F}$ of CFU-s from spleen and bone marrow in the presence of an almost compensated anemia, and decreased serum levels of SHSF. The study of the $\mathrm{Sl}^{j}$ trait may be a useful extension of the current $\mathrm{Sl} / \mathrm{Sl}^{\mathrm{d}}$ model for exploration of hereditary defects in haematopoietic stroma.
\end{abstract}

From a series of alleles detected at the highly mutable 'steel' locus on chromosome 10 in mice (Russell \& Bernstein, 1966) the 'Steel-Dickie' (Sld/Sld or $\mathrm{Sl} / \mathrm{Sl}{ }^{d}$ ) allele combinations have

Correspondence: Dr R. E. Ploemacher, Department of Cell Biology and Genetics, Erasmus University, P.O. Box 1738, 3000 DR Rotterdam, The Netherlands. 
received much attention in the past 26 years with respect to the associated haematological anomalies (Russell, 1979). The Sld $/ \mathrm{Sl}^{d}, \mathrm{Sl} / \mathrm{Sl}^{d}$ and all heterozygote mice survive birth, but both $\mathrm{Sl} / \mathrm{SI}$ and $\mathrm{Sl}^{\mathrm{j}} / \mathrm{SI}^{\jmath}$ genotypes result in pre-natal death. Adult mice, homozygous for the 'steel' locus, are characterized by severe macrocytic normochromic anaemia, lack of hair pigmentation and sterility. The observations that $\mathrm{Sl} / \mathrm{Sl}^{\mathrm{d}}$ mice have an essentially nonerythropoietic spleen, a quantitative deficiency of early erythrocytic precursors in spleen, bone marrow (Wiktor-Jedrzejczak et al., 1979) and blood (McCarthy \& MacVittie, 1975) and a defective microenvironment for macroscopic erythrocytic spleen colonies (McCulloch et al., 1965; Wolf, 1974) in conjunction with high serum erythropoietin levels (Bernstein, Russell \& Keighley, 1968) have supported the view that the major disruption of erythropoiesis is early and more severe than in the granulocytic cell population (McCarthy, Ledney \& Mitchell, 1973; Cole et al., 1975).

The haematopoietic stroma in the deficient mice is considered to lack a positive proliferative stimulus for colony formation (Wolf, 1978a, b) and this defect is probably located in a relatively radioresistant stromal cell class (Fried et al., 1973a). A small complement of normal cells appears to be adequate to ensure normal erythropoiesis permanently in mosaic mice carrying a preponderance of the 'steel' locus (Mintz \& Cronmiller, 1978). Alleviation of the anaemia can only be produced by transplanting a normal spleen but not by normal stem-cell transfusions (Bernstein, 1970).

The evidence obtained so far indicates that the anaemia has a dual nature and is due not only to a defect in the haematopoietic microenvironment but as well as to a 5-10-fold increased periodic loss of blood via the intestinal tract (Kales, Fried \& Gurney, 1966; Wolf, 1978a). In our opinion, such a dramatic blood loss might obfuscate the study of the stromal defect in $\mathrm{Sl} / \mathrm{Sl}^{d}$ mice, since experimentally induced anaemia in mice has been shown to be associated with considerable changes in the population size of CFU-s, BFU-e and CFU-e in spleen and femur (Hara \& Ogawa, 1976, 1977; Ploemacher, Van Soest \& Vos, 1977). In a previous study (Brockbank \& Ploemacher, 1983), we have shown that $\mathrm{Sl}^{\mathrm{j}} /+$ mice have a normal low erythrocyte loss via their gut. The $\mathrm{Sl}^{\mathrm{J}}$ locus has been demonstrated to have effects upon haematopoiesis in fetuses homozygous for the $\mathrm{Sl}^{\jmath}$ allele (Cole et al., 1975) and in allophenic mice formed by injection of OTT 6050 male teratocarcinoma (129 strain) transplant line germ cells into normal WH blastocysts (Mintz \& Cronmiller, 1978). Both groups of authors agree on the notion that the primary lesion in the anaemia resides in the haematopoietic microenvironment. To investigate the applicability of the $\mathrm{Sl}^{\mathrm{J}}$ model in stroma-related research we have characterized the CFU-s population of adult 129 mice, heterozygous for the $\mathrm{Sl}^{\mathrm{j}}$ allele and their normal littermates, with respect to organ distribution, seeding behaviour, colony formation, radiosensitivity and humoral regulation. Attempts were also made to investigate stromal function and humoral CFU-s regulation in these mice. Our results indicate that the $\mathrm{Sl}^{\mathrm{j}} /+$ gene complement is associated with a stromal defect, which causes a significant deficiency of CFU-s in their spleen, blood and bone marrow.

\section{MATERIALS AND METHODS}

\section{Animals}

$129 / \mathrm{SvSl}^{\mathrm{j}} \mathrm{CP}$ mice of both sexes were derived from animals originally obtained from the Jackson Laboratory, Bar Harbor, Maine, U.S.A. Sl $1++$ and normal $+1+$ mice were bred at the Laboratory Animal Centre of the Erasmus University by natural matings between male S $\mathrm{J} /+$ and female $+1+$ mice, yielding $50 \%+1+$ and $50 \% \mathrm{Sl}^{\mathrm{J}} /+$ segregants. Selection of the defective mice could be made from their lighter grey-brownish coat (agouti) with scattered grey hairs and diminished pigmentation of their feet and tail end. The mice were used at 12-20 weeks of 
age. Male C57BL/Rij mice, 48-54 weeks of age, were purchased from the Dutch Reactor Centre in Petten, and 4-10 week-old male WCB6F1/J mice were obtained from Jackson Laboratory and maintained at the Erasmus University under clean conventional conditions. The animals were maintained under constant light. Food pellets and acidified $(\mathrm{pH} 2 \cdot 5)$ water were available ad libitum.

\section{Blood analyses}

Blood was withdrawn from the retro-orbital sinus under ether anaesthesia and collected in heparinized tubes. Standard procedures were employed to measure red blood cells (RBC) and nucleated cell numbers in a Coulter particle counter and to determine the haematocrit (Hct) in an International microcapillary centrifuge. The mean cell volume (MCV) of RBC was calculated from the preceding data.

\section{Assays for in-vivo colony formation and CFU-s seeding efficiency}

A Gammacell 40 Caesium 137 irradiation unit (Atomic Energy of Canada Ltd, Ottawa) was used to irradiate animals and cell suspensions in vitro. Total body irradiation at a dose rate of $1.31 \mathrm{~Gy} \min ^{-1}$ was used for recipients in the in-vivo colony-forming assays. A modified logarithmic transformation was used for evaluation of the endogenous colony counts to correct for their skewed distribution (Smith, Budd \& Cornfield, 1966).

The CFU assay of Till and McCulloch (1961) was performed using both 9 Gy irradiated $\mathrm{Sl}^{\mathrm{J}} /+$ and $+/+$ mice as recipients. The 24 -hr seeding efficiencies ' $\mathrm{f}$ ' of CFU-s were determined according to the method of Siminovitch, McCulloch and Till (1963). Briefly, femoral marrow or spleen cells from pools of three $\mathrm{Sl}^{j} /+$ or $+/+$ mice were injected i.v. into three or four intermediate recipients with $\mathrm{Sl}^{\mathrm{l}} /+$ or $+/+$ gene complements. Twenty-four hr later the mice were killed, their spleens removed, and $1 / 5$ to $1 / 10$ of a spleen was than injected into $10+/+$ secondary recipients. The CFU-s content of the original cell suspensions was determined in 10 primary recipients by the in-vivo CFU-s assay. In-vitro irradiated spleen and marrow cells were transplanted into lethally irradiated recipient mice within $3 \mathrm{hr}$ following irradiation. In both the transplant assay and the endogenous spleen colony assay spleens were fixed in Bouin Hollande's fluid on day 8 following irradiation. Diameters of spleen surface colonies were then estimated in tenths of a mm using an inverted microscope and a fine-scale transparent matrix.

\section{Implantation method}

Spleens and femurs were removed after killing implant donors by cervical dislocation. They were freed of fat and tendons, respectively, and eight small incisions were made in the splenic hilus to ensure optimal regeneration. The epiphyseal ends of the femurs were cut off and spleens and femurs were placed in ice-cold saline containing $10^{6} \mathrm{U}$ penicillin and $1.0 \mathrm{~g}$ of streptomycin litre ${ }^{-1}$ while the hosts were being prepared for the implantation. Host mice were anaesthetized with Nembutal. The abdominal skin was vertically incised over the midline and undermined for a distance of about $1 \frac{1}{2} \mathrm{~cm}$ in each direction using blunt-tipped forceps. The organs to be implanted were s.c. positioned as far from the incision as possible and the wound closed. Each host received one spleen or two femurs. Six weeks later, the implants were removed and their cellularity and CFU-s content determined.

\section{Detection system for splenic haemopoiesis-stimulating factor (SHSF)}

The serum activity of SHSF (Staber \& Metcalf, 1980a, b) was quantified in vivo by measurement of the splenic CFU-s accumulation induced by injection of the respective sera. Blood was obtained sterilely from unperturbed $+/+$ and $\mathrm{Sl}^{\mathrm{j}} /+$ mice and clotting was allowed 
for $1 \mathrm{hr}$ at room temperature. After storage at $4{ }^{\circ} \mathrm{C}$ overnight, serum was collected by two consecutive centrifugations at $500 \mathrm{~g}$ and stored at $-20^{\circ} \mathrm{C}$ until use. The level of pyrogens in the sera was estimated using the Limulus amoebocyte lysate assay as described by Thomas $e t$ al. (1981). Four days after $+/+$ and $\mathrm{Sl}^{\mathrm{j}} /+$ mice had been i.p. injected with $0.3 \mathrm{ml}$ of the respective sera, their spleens were removed and the CFU-s content determined using the CFU assay of Till and McCulloch (1961).

\section{RESULTS}

\section{Colony-forming ability of $+/+$ and $\mathrm{SI} /+$ haematopoietic cells in normal $+/+$ and anaemic $\mathrm{SP} /+$ recipients}

From Table 1 it is apparent that $\mathrm{Sl}^{\mathrm{J}} /+$ mice have a mild macrocytic anaemia. Red blood cell (RBC) numbers and MCV values showed no overlap in the two congenic groups, while Hct values differed slightly but significantly. No sex differences were observed in the peripheral blood picture. Leucocyte numbers in $\mathrm{Sl}^{\mathrm{j}} /+$ mice were similar to those found in their normal littermates. Significantly less circulating CFU-s were found in the $\mathrm{Sl}^{\mathrm{j}} /+$ blood.

No significant differences in the femoral and splenic cellularity were noted between $+1+$ and $\mathrm{Sl}^{\mathrm{j}} /+$ mice (Table 2). A slightly lower colony-forming ability (75\%) of $\mathrm{Sl}^{\mathrm{j}} /+$ femoral cells

Table 1. Some haematological parameters in strain 129 mouse blood

\begin{tabular}{|c|c|c|c|c|}
\hline & \multicolumn{2}{|c|}{$+1+$} & \multicolumn{2}{|c|}{$\mathrm{Sl}^{\mathrm{l}} /+$} \\
\hline & Males & Females & Males & Females \\
\hline Het $(\%)$ & $49.99(0.36)^{*}$ & $49.33(0.64)$ & $47.23(0.65)$ & $47.25(0.67)$ \\
\hline Erythrocytes $\mathrm{ml}^{-1}\left(\times 10^{9}\right)$ & $8.64(0.39)$ & $9.43(0.28)$ & $7.72(0.24)$ & $8 \cdot 10(0 \cdot 12)$ \\
\hline $\operatorname{MCV}\left(\mu \mathrm{m}^{3}\right)$ & $55.68(1.21)$ & $51.83(1.02)$ & $60.31(2.03)$ & $58.13(1.79)$ \\
\hline Leucocytes $\mathrm{ml}^{-1}\left(\times 10^{6}\right)$ & $11.48(3 \cdot 23)$ & $11.68(2.26)$ & $11 \cdot 53(2 \cdot 38)$ & $10.88(1.76)$ \\
\hline CFU-s ml ${ }^{-1}$ & \multicolumn{2}{|c|}{$49(3)+$} & \multicolumn{2}{|c|}{$19(6)$} \\
\hline
\end{tabular}

* Arithmetic mean of twelve experiments (1 SE).

+ Arithmetic mean of four experiments (1 SE). In two experiments male mice were used. All mice were 20 weeks of age. Colony formation was assayed in normal $+/+$ mice.

Table 2. Femoral and splenic cellularity and CFU-s incidence in strain 129 mice

\begin{tabular}{|c|c|c|c|c|}
\hline & \multicolumn{2}{|c|}{ Femur } & \multicolumn{2}{|c|}{ Spleen } \\
\hline & $+1+$ & $\mathrm{Sl}^{\mathrm{l}} /+$ & $+1+$ & $\mathrm{Sl}^{\mathrm{j}} /+$ \\
\hline \multicolumn{5}{|l|}{ Cellularity $\times 10^{7}$} \\
\hline males & $2.77(0.41)^{*}$ & $2 \cdot 14(0.28)$ & $16 \cdot 5(0.5)$ & $16 \cdot 3(0.9)$ \\
\hline females & $2.04(0.18)$ & $1.94(0.22)$ & $15 \cdot 8(1 \cdot 3)$ & $15 \cdot 4(1 \cdot 0)$ \\
\hline males + females & $2 \cdot 41(0.25)$ & $2.04(0.17)$ & $16 \cdot 0(0.8)$ & $15.7(0.7)$ \\
\hline \multicolumn{5}{|c|}{ CFU-s $10^{-7}$ nucl. cells } \\
\hline males & $2279(384)$ & $2464(758)$ & $281(62)$ & $149(60)$ \\
\hline females & $2124(230)$ & $1583(304)$ & $325(33)$ & $135(22)$ \\
\hline males + females & $2221(224)$ & $1916(440)$ & $300(30)$ & $140(22)$ \\
\hline
\end{tabular}

* Arithmetic mean (I SE) of three (male) or eight (female) separate experiments. Colony formation was assayed in normal $+/+$ mice. 
Table 3. Seeding efficiency ( $24 \mathrm{hr}$ ) of femoral and splenic cells in 129 mice

\begin{tabular}{cccc}
\hline \multirow{2}{*}{$\begin{array}{c}\text { Cell } \\
\text { suspension } \\
\text { from }\end{array}$} & Donor & lst recipient & $\begin{array}{c}24 \mathrm{hr} \\
\text { seeding* }\end{array}$ \\
\cline { 2 - 4 } Spleen & $+/+$ & $+/+$ & $2.66 \pm 0.27 \dagger$ \\
& $\mathrm{Sl}^{\mathrm{j} /+}$ & $+/+$ & $3.70 \pm 0.66$ \\
& $+/+$ & $\mathrm{Sl}^{\mathrm{J}} /+$ & $2.94 \pm 0.27$ \\
Spleen & $+/+$ & $+/+$ & $2.47 \pm 0.22$ \\
& $\mathrm{Sl} /+$ & $+/+$ & $2.41 \pm 0.66$ \\
& $+/+$ & $\mathrm{Sl} /+$ & $3.92 \pm 0.66$ \\
\hline
\end{tabular}

* The percentage of seeded CFU-s was expressed relative to the number of colonies evoked by injection of cells into $+/+$ recipients. Second recipients were normal $+/+$ mice.

$\dagger$ Arithmetic mean of three separate experiments $\pm 1 \mathrm{SE}$.

was found in females. In contrast, the colony-forming potential of the $\mathrm{Sl}^{\mathrm{j}} /+$ spleen cells was observed to be only $42-53 \%$ of $+/+$ spleen cells in both males and females.

From Table 3 it is apparent that the 24-h seeding efficiency of both $\mathrm{Sl}^{\mathrm{j}} /+$ bone marrow and spleen cells was not significantly different from that of $+/+$ cells. Also, $+/+$ bone marrow and spleen cells had similar $24-\mathrm{h}$ seeding efficiencies in irradiated $+/+$ and $\mathrm{Sl} /+$ recipient mice. These observations imply that the data presented in Tables 2, 4 and 5 have a realistic basis and do not require correction for differences in seeding efficiency.

In Table 4 the femoral and splenic CFU-s content is listed according to the sex of the mice. Irrespective of the genotype of the irradiated recipients, $\mathrm{Sl}^{\mathrm{J}} /+$ femurs were found to have slightly less CFU-s per femur and a significantly reduced splenic CFU-s content. The data also clearly demonstrate that the $\mathrm{Sl}^{\mathrm{j}} /+$ splenic microenvironment is defective in its ability to optimally stimulate colony formation of bone marrow or spleen cells whether derived from $+/+$ or $\mathrm{Sl}^{\mathrm{j}} /+$ animals. The deficient colony number per spleen cannot be explained by a lower 24-hr seeding efficiency of $+/+$ CFU-s in the anaemic recipients (Table 3 ).

Because of relatively large variations between the separate experiments influencing standard errors, the data from Table 4 have been expressed as percentages of the $+1+$ femoral

Table 4. Femoral and splenic CFU-s content in strain 129 mice

\begin{tabular}{|c|c|c|c|c|c|}
\hline \multirow{2}{*}{$\begin{array}{l}\text { Genotype } \\
\text { recipient" }\end{array}$} & \multirow[b]{2}{*}{ Sex } & \multicolumn{2}{|c|}{ Femur } & \multicolumn{2}{|c|}{ Spleen } \\
\hline & & $+1+$ & $\mathrm{Sl}^{\mathrm{j} /}+$ & $+/+$ & $\mathrm{Sl}^{\mathrm{J}} /+$ \\
\hline$+/+$ & & $4627(524)$ & $3723(529)$ & $5457(639)$ & $1915(355)$ \\
\hline $\mathrm{Sl}^{j /+}+$ & O† & $3236(327)$ & $2943(369)$ & $3406(509)$ & $1486(300)$ \\
\hline$+1+$ & & $6664(382)$ & $5178(1196)$ & $4191(1067)$ & $1797(467)$ \\
\hline $\mathrm{Sl}^{\mathrm{j}} /+$ & $\partial t$ & 4489 (498) & $4305(665)$ & $2779(280)$ & $1332(677)$ \\
\hline
\end{tabular}

* Lethally irradiated recipient in spleen colony assay.

$\dagger$ Presented are the arithmetic means $( \pm 1$ SE) of eight separate experiments in which female mice of 15-54 weeks of age were used.

$\ddagger$ Presented are the arithmetic means $( \pm 1 \mathrm{SE}$ ) of three separate experiments in which male mice of 11-39 weeks of age were used. 
Table 5. Colony formation in $+/+$ and $\mathrm{Sl}^{\mathrm{l}} /+$ recipient mice

\begin{tabular}{|c|c|c|c|c|}
\hline \multirow{2}{*}{$\begin{array}{l}\text { Genotype } \\
\text { recipient }\end{array}$} & \multicolumn{2}{|c|}{ Femur } & \multicolumn{2}{|c|}{ Spleen } \\
\hline & $+1+$ & $\mathrm{sl}^{\mathrm{J}} /+$ & $+1+$ & $s s^{\mathrm{J}} /+$ \\
\hline$+1+$ & 100 & $\begin{array}{l}82.42 \\
(10.89)\end{array}$ & 100 & $\begin{array}{l}36 \cdot 93 \\
(3-46)\end{array}$ \\
\hline $\mathrm{Sl}^{\mathrm{j}} /+$ & $\begin{array}{l}70.07 \\
(3.83)\end{array}$ & $\begin{array}{l}65.74 \\
(6.86)\end{array}$ & $\begin{array}{l}65.98 \\
(6.65)\end{array}$ & $\begin{array}{l}26.86 \\
(3.08)\end{array}$ \\
\hline $\begin{array}{l}\text { ratio }+/+ \text { vs. } \mathrm{S}^{\mathrm{j}} /+ \\
\text { recipient }\end{array}$ & 70.07 & 79.76 & 65.98 & 72.73 \\
\hline
\end{tabular}

Number of CFU-s organ ${ }^{-1}$ expressed as $\%+/+$ CFU-s forming colonies in irradiated $+1+$ recipients.

Arithmetic mean of $10-11$ experiments with $1 \mathrm{SE}$ in parentheses.

and splenic CFU-s content as determined in $+/+$ recipients (Table 5). The observation that the colony number reduction in $\mathrm{Sl}^{\mathrm{J}} /+$ hosts was constant (approximately 30\%) irrespective of the origin of the infused cells, suggests that $+/+$ and $\mathrm{Sl}^{j} /+$ CFU-s have comparable sensitivities to the proliferative stimulus for colony formation exerted by the hosts' spleen.

The mean diameter of the four largest colonies per spleen evoked by injection of $+1+$ bone-marrow cells and spleen cells in normal and defective recipients was not significantly different. Femoral cells formed colonies with a mean diameter of $1.12 \mathrm{~mm}(1 \mathrm{SE}, 0.03)$ in $+/+$ recipients and $1.03(0.03) \mathrm{mm}$ in $\mathrm{Sl}^{\mathrm{j}} /+$ recipients. For splenic cells these data were respectively $1.08(0.03) \mathrm{mm}$ in $+/+$ recipient mice and $1.07(0.04) \mathrm{mm} \mathrm{in} \mathrm{Sl} /+$ mice.

\section{Haematopoiesis in implanted spleens and femurs}

At 6 weeks' post-implantation, following the regeneration of the splenic and femoral stroma, the cellularity and CFU-s number (Table 6$)$ of $+/+$ implants exceeded that of $\mathrm{Sl}^{\mathrm{j}} /+$ implants

Table 6. CFU-s content and cellularity of implanted $+/+$ and $\mathrm{Sl}^{\mathrm{j}} /+$ spleens and femurs as function of the host status

\begin{tabular}{|c|c|c|c|c|c|}
\hline \multirow{3}{*}{$\begin{array}{l}\text { Organ } \\
\text { content }\end{array}$} & \multirow{3}{*}{$\begin{array}{c}\text { Host } \\
\text { (genotype/status) }\end{array}$} & \multicolumn{4}{|c|}{ Implanted organs } \\
\hline & & \multicolumn{2}{|c|}{ Spleen } & \multicolumn{2}{|c|}{ Femur } \\
\hline & & $+1+$ & $\mathrm{Sl}^{\mathrm{j}} /+$ & $+1+$ & $\mathrm{SI}^{j} /+$ \\
\hline CFU-s & $\begin{array}{c}+/+ \\
\mathrm{Si}^{\mathrm{b} /+} \\
+/+(\text { irr }) \dagger\end{array}$ & $\begin{array}{l}58(25) \ddagger \\
120(9) \\
225(16)\end{array}$ & $\begin{array}{l}22(11) \\
37(27) \\
51(4)\end{array}$ & $\begin{array}{c}1061(122) \\
715(140) \\
1054(60)\end{array}$ & $\begin{array}{l}601(151) \\
608(124) \\
832(248)\end{array}$ \\
\hline Cellularity $\times 10^{6}$ & $\begin{array}{c}+/+ \\
\mathrm{Sl}^{\mathrm{j}} /+ \\
+/+(\mathrm{irr})\end{array}$ & $\begin{array}{l}14.28(3.81) \\
19.61(2.66) \\
15.00(0.08)\end{array}$ & $\begin{array}{r}8.90(1.06) \\
10.46(2.59) \\
8.80(1.98)\end{array}$ & $\begin{array}{r}8.38(1.15) \\
11.08(1.18) \\
10.84(1.23)\end{array}$ & $\begin{array}{l}8.29(1.19) \\
8.05(0.86) \\
8.64(2.77)\end{array}$ \\
\hline
\end{tabular}

- Lethally irradiated $+1+$ mice were used in the CFU-s assay.

+ Hosts received $5 \mathrm{~Gy}$ total body irradiation 2 days before organs were implanted.

₹ Arithmetic mean of four separate experiments ( $1 \mathrm{SE}$ ). 
Table 7. Effects of serum from mice carrying the 'steel' allele and their normal littermates on spleen CFU-s levels

\begin{tabular}{cccc}
\hline \multirow{2}{*}{$\begin{array}{c}\text { Normal } \\
\text { serum } \\
\text { injected }\end{array}$} & \multicolumn{3}{c}{ Splenic CFU-s content $\left(\times 10^{3}\right)$} \\
\cline { 2 - 4 } & $+/+$ mice & S1 $1 /+$ mice & C57BL/Rij mice \\
\hline None & $4.2(1.1)$ & $1.8(0.5)$ & $6.6(2.4)$ \\
$+/+^{*}$ & $12.7(1.4)$ & $5.3(0.8)$ & - \\
$\mathrm{Sl}^{j} /+$ & $8.1(0.4)$ & $2.5(0.7)$ & - \\
$+/+\dagger$ & - & - & $9.8(2.7)$ \\
$\mathrm{Sl}^{\prime} \mathrm{Sl}^{d}$ & - & - & $18.2(4.9)$ \\
\hline
\end{tabular}

* $0.3 \mathrm{ml}$ of serum was injected i.p. Mice were killed 4 days later. The serum batch was prepared by pooling the sera from 80 mice per experimental point.

$\dagger$ At 0,6 and $24 \mathrm{hr} 0.1 \mathrm{ml}$ of serum was injected i.p. Mice were killed at day 4.

$\ddagger$ Arithmetic mean $( \pm 1 \mathrm{SE})$ of three individually assayed mice.

in both $+/+$ and $\mathrm{Sl}^{\mathrm{j}} /+$ hosts. The CFU-s content of splenic implants in $\mathrm{Sl}^{\mathrm{j}} /+$ hosts and preirradiated $+/+$ hosts exceeded that in $+/+$ hosts. The latter observation indicates that $\mathrm{Sl}^{\mathrm{J} /}+$ mice, similar to irradiated mice, have higher levels of undefined systemic factors, which enhance the implant regeneration.

\section{The SHSF level in normal serum of $\mathrm{SP} /+$ and $\mathrm{SI} / \mathrm{Sl}^{d}$ mice and their respective normal $+/+$ littermates}

In order to investigate whether the serum of $\mathrm{Sl}^{\mathrm{J}} /+$ mice also contained higher levels of a factor which would activate CFU-s to proliferate in the spleen (SHSF-splenic haemopoiesis stimulating factor), $0.3 \mathrm{ml}$ of normal $+/+$ or $\mathrm{Sl}^{\mathrm{j}} /+$ serum was injected i.p. into both normal and mutant mice. Four days later an enhanced splenic CFU-s content in $+1+$ and $\mathrm{Sl}^{\mathrm{j}} /+$ mice was observed (Table 7). The spleen of both $\mathrm{Sl}^{\mathrm{j}} /+$ mice and their normal littermates contained significantly more CFU-s following injection of $+/+$ serum than following $\mathrm{Sl}^{\mathrm{j}} /+$ serum. This observation suggests that $\mathrm{Sl}^{\mathrm{j}} /+$ mice do not show increased humoral stimulation of CFU-s proliferation in an attempt to compensate for the deficient splenic CFU-s content.

From Table 7 it is also apparent that normal mouse serum from $\mathrm{Sl} / \mathrm{Sl}^{\mathrm{d}}$ mice was significantly more potent than was serum from their normal $+/+$ littermates in evoking a splenic CFU-s accumulation in the spleen of C57BL/Rij mice. This relatively high serum $\mathrm{SHSF}$ level in $\mathrm{Sl} / \mathrm{Sl}^{\mathrm{d}}$ mice suggests that these stromal-defective mice exert an increased systemic stimulus for CFU-s proliferation in response to the severe macrocytic anaemia suffered by these mice.

\section{Endogenous colony formation}

Upon sublethal irradiation, surviving CFU-s formed colonies in the irradiated animal's spleen and bone marrow. $\mathrm{Sl}^{\mathrm{j}} /+$ mice of both sexes were characterized by a lower endogenous spleen colony formation than occurred in $+/+$ mice (Fig. 1). The average difference in the $3 \cdot 3-7 \cdot 0$ Gy range was 5.7 for females and 3.1 for males. The endogenous CFU-s of $+/+$ origin were characterized by $\mathrm{a}_{37}$ of $0.93 \mathrm{~Gy}$ for females and $0.84 \mathrm{~Gy}$ for males, whereas $D_{37}$ values for $\mathrm{S}^{\mathrm{j}} /+$ females were $0.75 \mathrm{~Gy}$ and for males $0.77 \mathrm{~Gy}$. 


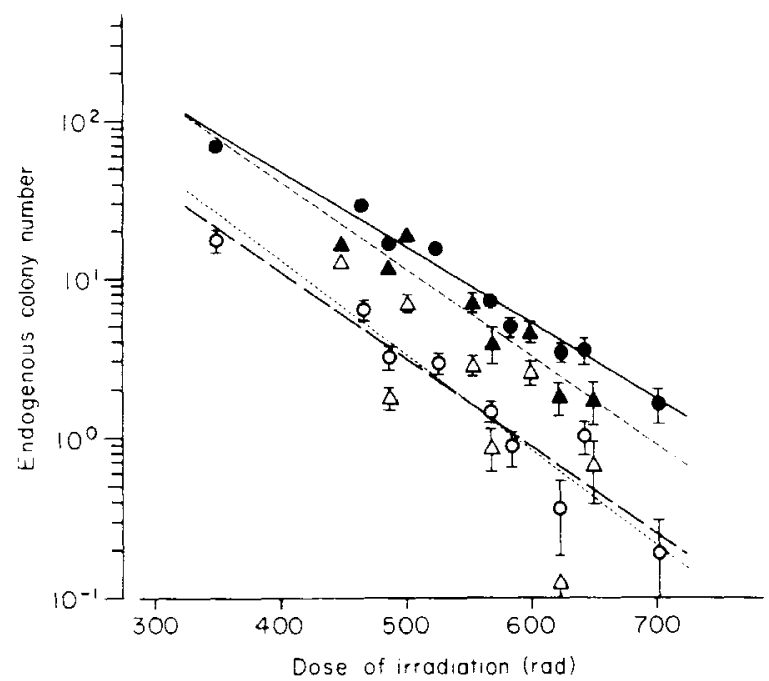

Fig. 1. Radiosensitivity of endogenous spleen colony-forming cells. A logarithmic transformation according to Smith et al. (1966) was employed to correct for the skewed endogenous colony distribution. Open symbols refer to $\mathrm{Sl}^{\mathrm{j}} /+$ mice $\left(\mathrm{D}_{37}=0.75-0.77 \mathrm{~Gy}\right)$. solid symbols to $+/+$ mice $\left(D_{37}=0.84-0.93 \mathrm{~Gy}\right)$. The circular symbols represent females, the triangles males. Presented are the results of separate experiments as the mean colony count on ten spleens (1 SE) per experimental point. SE bars, which are not indicated in the figure, fall within the limits of the symbols used.

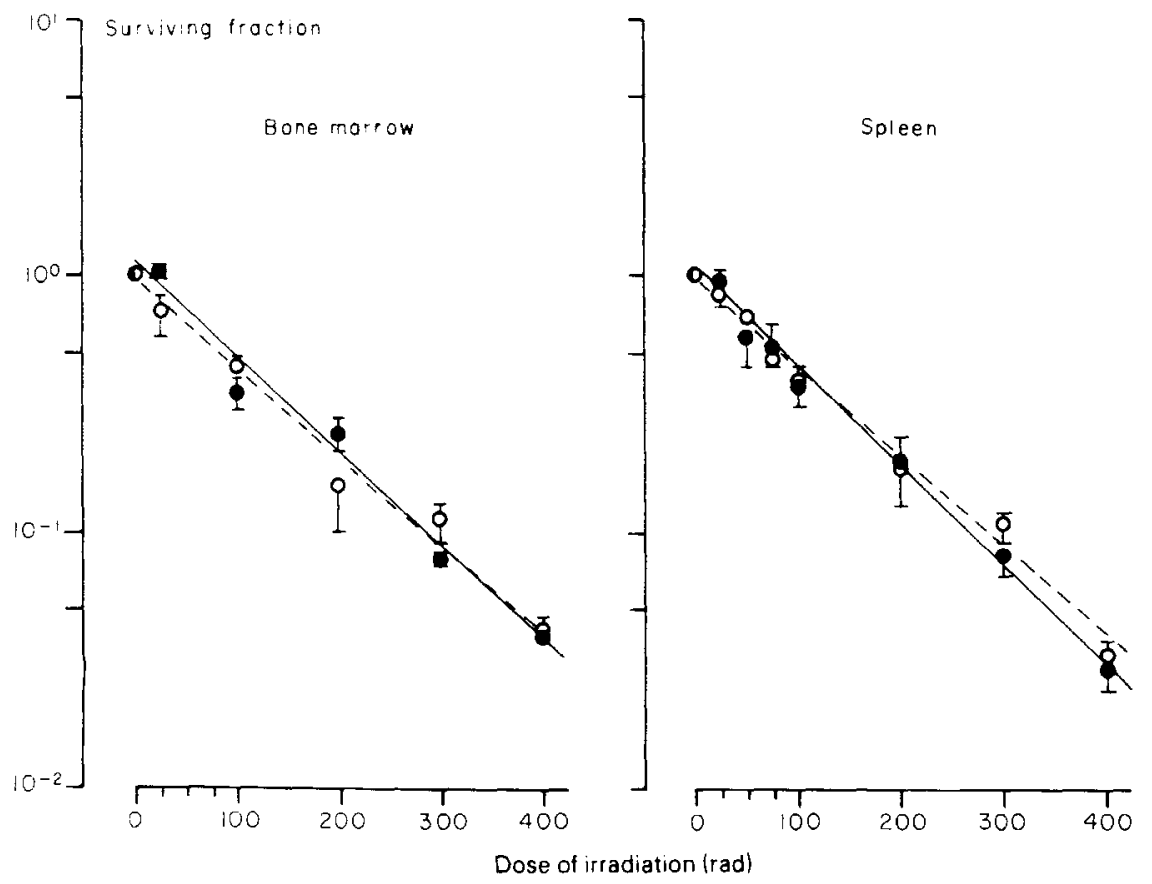

Fig. 2. Survival curve for in-vitro irradiated CFU-s from spleen and bone marrow. Open symbols refer to $\mathrm{Sl}^{j} /+$ mice, solid symbols to $+1+$ mice. Presented are the arithmetic mean $( \pm 1 \mathrm{SE})$ of nine individual experiments. Marrow CFU-s of $+1+$ mice had $a D_{37}$ of 1.22 Gy and extrapolation number of $1 \cdot 13 . D_{37}$ for $\left.S\right]^{j} /+$ marrow was 1.37 Gy, extrapolation number 0.98 . Spleen CFU-s of $+/+$ mice, $D_{3}$, of 1.13 Gy, extrapolation number 1.10 ; $\mathrm{Sl}^{\mathrm{j}} /+$ spleen CFU-s had a $\mathrm{D}_{37}$ of 1.27 Gy and extrapolation number of 0.98 . 


\section{Radiosensitivity of CFU-s}

The $\gamma$-radiation survivial of in-vitro irradiated spleen and bone marrow CFU-s of $+/+$ and $\mathrm{Sl}^{\mathrm{j}} /+$ female mice is shown in Fig. 2. The survival curve for $+/+$ marrow CFU-s had a $\mathrm{D}_{37}$ of $1.22 \mathrm{~Gy}$ and an extrapolation number of 1.13 and did not differ significantly from that of $\mathrm{Sl}^{\mathrm{J}} /+$ marrow CFU-s $\left(\mathrm{D}_{37}, 1.37 \mathrm{~Gy}\right.$; extrapolation number 0.98). Spleen CFU-s from mutant and normal littermates also showed similar radiation-survival characteristics. The $\mathrm{D}_{37}$ of the survival curve for $+/+$ spleen CFU-s was 1.13 Gy with an extrapolation number of $1 \cdot 10$, while $\mathrm{SI}^{\mathrm{H}} /+$ spleen $\mathrm{CFU}-\mathrm{s}$ ahd $\mathrm{a}_{37}$ of $1.27 \mathrm{~Gy}$ and an extrapolation number of 0.98 .

\section{DISCUSSION}

The present data form a first attempt toward a characterization of the CFU-s population in adult 129 mice carrying the $\mathrm{Sl}^{\mathrm{j}} /+$ and $+/+$ gene complements. They extend the observation on a microenvironmental lesion caused by the $\mathrm{Sl}^{\mathrm{j}}$ allele. The $\mathrm{Sl}^{\mathrm{j}} /+$ mice have a mild but definite macrocytic anaemia. Their circulating and splenic CFU-s were found to be reduced (being 39 and $42 \%$ of $+/+$ mice respectively) and the femoral CFU-s content (82\%) was subnormal (Tables 1 and 5). It might be argued that the reduction in splenic and peripheral-blood CFU-s seen in $\mathrm{Sl}^{\mathrm{j}} /+$ mice is not due to reduced numbers of true pluripotent CFU-s but to reduction of erythroid-committed stem-cell progenitors relative to myeloid committed progenitors, which may contribute to colony formation (Kretchmar \& Conover, 1970). However, the BFU-e and CFU-g/m population size have been demonstrated to be similarly reduced both in spleen and femur of $\mathrm{Sl}^{\mathrm{l}} /$ + mice, rendering this possibility unlikely (Brockbank \& Ploemacher, 1983).

It has been suggested that there is a strong stimulus for differentiation in $\mathrm{Sl} / \mathrm{Sl}^{d}$ mice, which sustains a normal splenic CFU-s content despite the apparent defect of the splenic stroma (Wolf, 1974; Bernstein et al., 1968; McCarthy, Ledney \& Mitchell, 1977; Harrison, Malathi \& Silber, 1975; McCarthy, 1977). We propose that this strong stimulus may be absent in $\mathrm{Sl}^{\mathrm{j}} /+$ mice, due to the mild nature of the anaemia, resulting in a decreased CFU-s population, which is most evident in the spleen. Although we realize that only with extreme caution may one compare $\mathrm{Sl}^{j} /+$ and $\mathrm{Sl} / \mathrm{Sl}^{\mathrm{d}}$ mice, due to their different genetic background, direct support for this hypothesis has been obtained in the present experiments, which showed that $\mathrm{Sl}^{\mathrm{J}} /+$ mice had decreased serum levels of SHSF, whereas the SHSF level was increased in $\mathrm{Sl} / \mathrm{Sl}^{\mathrm{d}}$ mice as compared to their respective normal $+/+$ littermates. The SHSF has been suggested to be a single factor (Staber \& Metcalf, 1980b), which activates CFU-s to proliferate in the spleen. The accompanying rise in splenic levels of various haemopoietic progenitor cells has been held not to be mediated by the corresponding types of CSF (Staber \& Johnson, 1980). It seems unlikely that in $\mathrm{Sl}^{\mathrm{J}} /+$ and $\mathrm{Sl} / \mathrm{Sl}^{\mathrm{d}}$ mice the stromal defect is mediated by a defective SHSF or stem-cell-activating factor (SAF, Cerny, 1975) regulation, because both mutant mouse strains have a normal enhanced serum level of these regulators following lipopolysaccharide injection (Ploemacher et al., submitted for publication).

$\mathrm{Sl}^{j} /+$ mice were demonstrated to have a deficiency of endogenous spleen colony formation following sublethal doses of irradiation (Fig. 1). At least two factors may have contributed to this observation, i.e. (a) differences in the original splenic population size, and (b) differences in radiosensitivity of CFU-s. The latter possibility has to be disregarded since no differences in survival rate of $+/+$ and $\mathrm{Sl}^{\mathrm{J}} /+$ spleen and marrow CFU-s were observed following in-vitro $\gamma$ irradiation (Fig. 2). With respect to the first possibility, Table 5 implies that a $60 \%$ reduction of endogenous colony formation may be expected in $\mathrm{Sl}^{\mathrm{j}} /+$ spleens irrespective of possible differences in radiosensitivity. The observation that the reduction of the endogenous spleen colony formation was larger than $60 \%$ in the female $\mathrm{Sl}^{\mathrm{J}} /+$ mice may be due to a difference in 
the defective splenic support for the survival or proliferation of sublethally irradiated CFU-s. Similarly, such a difference in splenic support may be responsible for the observed sex differences. This observation strongly suggests that the local microenvironment is able to influence the survival rate of in-vivo irradiated CFU-s.

Two observations in the present study contributed to the notion, that $\mathrm{Sl}^{\mathrm{j}}+$ mice have a defective stroma of the haemopoietic organs. At first, normal and mutant CFU-s from both spleen and marrow formed less colonies in $\mathrm{Sl}^{\mathrm{j}} /+$ spleens than in $+/+$ spleens, The inhibition of colony formation was not caused by lower seeding fractions of these CFU-s into the $\mathrm{Sl}^{\mathrm{j}} /+$ spleens (Table 3), but apparently the seeded CFU-s were less stimulated than in normal $+1+$ spleens to form detectable colonies. Secondly, spleens and femurs of $+/+$ origin regenerated better than $\mathrm{Sl}^{\mathrm{j}} /+$ spleens and femurs as measured by the implanted organ's cellularity and CFU-s content. The haematopoietic cells which grow in such implants originate predominantly from host CFU-s (Amsel \& Dell, 1971; Fried et al., 1973b; Adler et al., 1980), whereas the supporting microenvironmental tissues are of donor origin (Friedenstein et al., 1968; Tavassoli et al., 1973; Wolf, 1982). It has been shown that increasing doses of X-rays given to the implant donors increasingly impair the ability of the implants to support haemopoiesis (Fried et al., 1976; Ploemacher \& Van Soest, 1979) and that freezing the tissues prior to implantation abolishes this ability (Fried et al., 1973a). These observations support the concept that the stromal factors determining implant regeneration are cellular. The present findings therefore suggest that in $\mathrm{Sl}^{\mathrm{j}} /+$ mice the stromal cell population, which is necessary to support CFU-s proliferation and maintenance, is either smaller than in normal mice and sparsely distributed, or its individual component cells are less effective, or both. This concept is consistent with the observations on the defective stroma in $\mathrm{Sl} / \mathrm{Sl}^{\mathrm{d}}$ mice (Fried et al., 1973a).

Splenic implants carried by $\mathrm{Sl}^{\mathrm{j}} /+$ hosts and preirradiated $+/+$ hosts contained more CFU-S than those in normal $+/+$ hosts (Table 5). This indicates that $\mathrm{Sl}^{\mathrm{j}} /+$ mice, similar to irradiated mice, have higher levels of as-yet-undefined systemic factors responsible for enhancement of splenic implant regeneration. Such systemic factors probably do not include SHSF (Table 7). The non-responsiveness of femoral implants to these factors might be explained by the observation that the total splenic mass in any one animal is controlled by certain factors (Crosby, 1963; Metcalf, 1963; Tavassoli et al., 1973), whereas that of the bone-marrow mass is not (Chertkov et al., 1980). This suggests that the spleen is more sensitive for the action of growth enhancing factors.

We conclude that the $\mathrm{Sl}^{\mathrm{j}} /+$ spleen shows defective $\mathrm{CFU}-\mathrm{s}$ maintenance under 'steady-state' conditions and that the local proliferative stimulus for colony formation (as measured by the number of developing colonies) is decreased or repressed by some unknown mechanism. At the same time the splenic stroma of $\mathrm{Sl}^{\mathrm{j}} /+$ mice is not defective in its capacity to lodge injected CFU-s. This evidence supports previous studies suggesting that lodging and proliferative stimulus for colony formation operate as distinctive functional entities within the haematopoietic microenvironments (Wolf, 1974, 1982; Ploemacher, Brons \& Van Soest, 1982). Among differences in a series of haematological parameters in $\mathrm{Sl}^{\mathrm{j}} /+$ and $+/+$ mice, the subnormal endogenous colony formation in the spleen is among the most characteristic features of the defect. The phenotypic expression of the $\mathrm{Sl}^{\mathrm{j}}$ allele at the level of the haemopoietic microenvironment and the CFU's population size is different to that of the $\mathrm{Sl}^{\mathrm{d}}$ allele. The $\mathrm{Sl}^{\mathrm{j}} /+$ gene combination therefore appears to be an interesting tool in haematological research.

\section{ACKNOWLEDGEMENTS}

The authors appreciate the advice of Dr K. G. M. Brockbank and Dr O. Vos in preparation of the manuscript. They also wish to thank $\mathrm{Mr} \mathrm{T}$. van $\mathrm{Os}$ and $\mathrm{Mr} \mathrm{W}$. J. Visser for the 
preparation of the figures and Ms Cary Meijerink-Clerkx for typing the manuscript. This investigation is part of a study on the regulation of haemopoiesis, which is supported by a programme grant of The Netherlands Foundation for Medical Research (FUNGO) and subsidized by the Netherlands Organization for the Advancement of Pure Research (ZWO).

\section{REFERENCES}

Amsel, S. \& Dell, E.S. (1971) Bone marrow repopulation of subcutaneously grafted mouse femurs. Proc. Soc. exp. Biol. 138, 555 .

Adler, S.S., Sawada, U. \& Trobaugh, F.E., Jr. (1980) Hemopoietic support capacity of W/W femurs and tibias. Exp. Hemat. 8, 666.

Bernstein, S.E. (1970) Tissue transplantation as an analytic and therapeutic tool in hereditary anemias. $A m$. J. Surgery, 119, 448.

Bernstein, S.E. Russell, E.S. \& Keighley, G. (1968) Two hereditary mouse anemias (Sl/Sl ${ }^{d}$ and W/W $\left.\mathrm{W}^{v}\right)$ deficient in response to erythropoietin. Ann. N.Y. Acad. Sci. 149, 475.

Brockbank, K.G.M. \& Ploemacher, R.E. (1983) Quantitation of stromal and hemopoietic progenitors in spleen and femoral marrow derived from steel $\left(\mathrm{S} \mathrm{l}^{\mathrm{j}} /+\right.$ and $\left.\mathrm{Sl} / \mathrm{Sl}^{\mathrm{d}}\right)$ mice and their normal littermates. Exp. Hemat. $11,467$.

Chertkov, J. L., Gurevitch, O.A. \& Udalov, G.A. (1980) Role of bone marrow stroma in hemopoietic stem cell regulation. Exp. Hemat. 8, 770 .

COLE, R.J., ReGAN, T., WhITE, S.L. \& CHEEK, E.M. (1975) Expression of congenital defects in the haemopoietic microenvironment. Erythroid and granulocyte-macrophage progenitor cells in prenatal 'steel' $\left(\mathrm{Sl}^{1 /} / \mathrm{Sl}^{\dagger}\right)$ anaemic mice. Cell Tissue Kinet. 8, 489.

Crosby, W.H. (1963) Hyposplenism: an inquiry into normal functions of the spleen. Ann. Rev. Med. $14,349$.

Curry, J.L. \& Trentin, J.J. (1967) Hemopoietic spleen colony studies. I. Growth and differentiation. Devel. Biol. $15,395$.

Fried, W., Chamberlin, W., Kedo, A. \& Barone, J. (1976) Effects of radiation on hematopoietic stroma. Exp. Hematol. 4, 310.

Fried, W., Chamberlin, W., Knospe, W.H., Husseini, S. \& Trobaugh, F.E., JR. (1973a) Studies on the defective haemopoietic microenvironment of $\mathrm{Sl} / \mathrm{Sl}^{\mathrm{d}}$ mice. Brit. J. Haematol. $24,643$.

Fried, W., Husseini, S., KNospe, W.H. \& Trobaugh, F.E., JR. (1973b) Studies on the source of hematopoietic tissue in the marrow of subcutaneously implanted femurs. Exp. Hemat. 1, 29.

Friedenstein, A.Y., Petrakova, K.V., Kurolesova, A.I. \& Frolova, G.P. (1968) Heterotopic transplants of bone marrow. Analysis of precursor cells for osteogenic and hematopoietic tissues. Transplantation, 6 , 230.

HARA, H. \& OGAWA, M. (1976) Erythropoietic precursors in mice with phenylhydrazine-induced anemia. $A m$. $J$. Hematol. 1, 453.

HaRA, H. \& OGaWA, M. (1977) Erythropoietic precursors in mice under erythropoietic stimulation and suppression. Exp. Hemat. 5, 141 .

Harrison, D. E., MALATHI, V.G. \& Silber, R. (1975) Elevated erythrocyte nucleoside deaminase levels in genetically anemic $\mathrm{W} / \mathrm{W}^{\mathrm{v}}$ and $\mathrm{Sl} / \mathrm{Sl}{ }^{\mathrm{d}}$ mice. Blood Cells, 1,605 .

HaRrison, D.E. \& Russell, E.S. (1972) The response of $\mathrm{W} / \mathrm{W}^{\mathrm{v}}$ and $\mathrm{Sl} / \mathrm{Sl}^{\mathrm{d}}$ anaemic mice to haemopoietic stimuli. Brit. J. Haematol. 22, 155.

Kales, A.N., FrIED, W. \& GuRney, C.W. (1966) Mechanism of the hereditary anemia of Sl ${ }^{\mathrm{m}}$ mutant mice. Blood, 28, 387.

Kretchmar, A.L. \& Conover, W.R. (1970) A difference between spleen-derived and bone marrow-derived colony-forming units in ability to protect lethally irradiated mice. Blood, 36, 772 .

MCCARThY, K.F. (1977) In vivo colony forming unit population sizes in hypertransfused $\mathrm{Sl} / \mathrm{Sl}^{\mathrm{d}} \mathrm{mice}$. In: Experimental Hematology Today (Ed. by S.J. Baum and G.D. Ledney) p. 81, Springer Verlag, New York.

McCarthy, K.F., Ledney, G.D. \& Mitchell, R. (1977) A deficiency of hematopoietic stem cells in steel mice. Cell Tissue Kinet. 10, 121.

MCCARThY, K.F. \& MACVITTIE, T.J. (1975) Erythrocytic committed hematopoietic stem cells in the peripheral blood of mice. Acta Haematologica, 53, 226.

McCulloch, E.A., Siminovitch, L., Till, J.E., Russell, E.S. \& Bernstein, S.E. (1965) The cellular basis of the genetically determined hemopoietic defect in anemic mice of genotype $\mathrm{Sl} / \mathrm{Sl}{ }^{\mathrm{d}}$. Blood, 26, 399.

MetCALF, D. (1963) Restricted growth capacity of multiple spleen grafts. Transplantation Bull. 2, 387.

Mintz, B. \& Cronmiller, C. (1978) Normal blood cells of anemic genotype in teratocarcinoma-derived mosaic mice. Proc. Natl. Acad. Sci. U.S.A. 75, 6247. 
Ploemacher, R.E.. Brons, N.H.C. \& van Soest, P.L. (1982) Relative stability of inductive properties versus adaptable support capacity for hemopoietic colony formation in the spleen. Exp. Hemat. 10, 187.

Ploemacher, R.E.. van Soest, P.L. \& Vos, O. (1977) Kinetics of erythropoiesis in the liver induced by phenylhydrazine. Scand. J. Haemalol. 19.424.

Ploemacher, R.E. \& van Soest, P.L. (1979) Haemopoietic stroma. I. Effects of radiation on proliferative and differential support capacity for haemopoiesis. IRCS Medical Science, 7, 234.

RuSSELL, E.S. (1979) Hereditary anemias of the mouse: a review for geneticists. In: Advances in Genetics $20,357$.

RusSell, E.S. \& Bernstein, S.E. (1966) Blood and blood formation. In: The Biology of the Laboratory Mouse (Ed. by E. L. Green) p. 351. McGraw-Hill, New York.

Siminovitch, R.. McCulloch. E.A. \& Till, J.E. (1963) The distribution of colony-forming cells among spleen colonies. J. Cell. Comp. Phys. 62. 327.

SMITH, W.W.. BUdD. R.A. \& CORNFIELD, J. (1966) Estimation of radiation dose-reduction factor for $\beta$-mercaptoethylamine by endogenous spleen colony counts. Rad. Res. 27, 363.

Staber, F.G. \& Johnson, G.R. (1980) The responses of hemopoietic precursor cells in mice to bacterial cell-wall components. J. Cell. Physiol. 105. 143.

Staber. F.G. \& MEtCalf. D. (1980a) Cellular and molecular basis of the increased splenic hemopoiesis in mice treated with bacterial cell wall components. Proc. Natl. Acad. Sci. USA, 77, 4322.

STABER. F.G. \& MetCalf. D. (1980b) Humoral regulation of splenic hemopoiesis in mice. Exp. Hematol. 8, 1094.

TAvassoli. M.. RatzaN, R.J. \& CRosby. W.H. (1973) Studies on regeneration of heterotopic splenic autotransplants. Blood. 41.701.

Thomas. L.L.M.. StuRk, A., Kahle, L.H. \& TEN CATE, J.W. (1981) Quantitative endotoxin determination in blood with a chromogenic substrate. Clin. Chim. Acta, 116, 63.

TILL, J.E. \& MCCULLOCH, E.A. (1961) A direct measurement of the radiation sensitivity of normal mouse bone marrow cells. Radiat. Res. 14. 213.

Wiktor-Jedrzejczak, W.. Ahmed, A.. Sharkis, S.J.. McKee, A. \& Sell, K.W. (1979) Defective transient endogenous spleen colony formation in Sl/Sld mice. J. Cell. Physiol. 99, 31.

WOLF, N.S. (1974) Dissecting the haematopoietic microenvironment. 1. Stem cell lodgment and commitment, and the proliferation and differentiation of erythropoietic descendants in the $\mathrm{SI} / \mathrm{Sl}$ d mouse. Cell Tissue Kinet. 7, 89.

Wolf, N.S. (1978a) Dissecting the haematopoietic microenvironment. II. The kinetics of the erythron of the $\mathrm{Sl} / \mathrm{Sl}^{\mathrm{d}}$ mouse and the dual nature of its anaemia. Cell Tissue Kinet. 11. 325.

Wolf, N.S. (1978b) Dissecting the haematopoietic microenvironment. IIl. Evidence for a positive short range stinuulus for cellular proliferation. Cell Tissue Kinet. 11. 335.

WOLF, N.S. (1982) Dissecting the hematopoietic microenvironment. IV. Regeneration of splenic microstructure. Prerequisites and chronology of reconstruction. Exp. Hematol. 10. 98. 